\title{
Macroeconomic Determinants of Real Wages in an Internationally Integrated Economy, Mexico 1998.1-2011.4
}

\section{Juan Carlos Márquez Ortiz ${ }^{1}$, Selene Jiménez Bautista²}

${ }^{1}$ The SMEs Administration and Management Educational Program, Universidad Politécnica Metropolitana de Hidalgo (UPMH), Tolcayuca, Mexico

${ }^{2}$ International Trade Department, Centro Universitario Nezahualcóyotl, Universidad Autónoma del Estado de México (UAEM), Toluca, Mexico

Email: jortiz@upmh.edu.mx

How to cite this paper: Ortiz, J.C.M. and Bautista, S.J. (2019) Macroeconomic Determinants of Real Wages in an Internationally Integrated Economy, Mexico 1998.12011.4. Modern Economy, 10, 1539-1557. https://doi.org/10.4236/me.2019.106102

Received: July 27, 2018

Accepted: June 25, 2019

Published: June 28, 2019

Copyright $\odot 2019$ by author(s) and Scientific Research Publishing Inc. This work is licensed under the Creative Commons Attribution International License (CC BY 4.0).

http://creativecommons.org/licenses/by/4.0/

\begin{abstract}
The objective of the current document is to analyze the macroeconomic determinants of real wages in Mexico, an economy with a high degree of integration with the US, under the Hypotheses of Rational Expectations, through the Generalized Method of Moments (GMM). We estimated an ad hoc wage-setting equation, to the Mexican economy. The outcomes validate the existence of a Phillips curve and show that the unemployment is the most important variable in determining the real salary rates. However, productivity keeps a close relation with wages, while the inflation expectations play a secondary role in determining them.
\end{abstract}

\section{Keywords}

Rational Expectations, Real Wage, Productivity, Generalized Method of Moments

\section{Introduction}

Real wage is undoubtedly one of the key variables in determining employment. For this reason, the economic theory grants it a prevailing place in the studies of the working market. Moreover, the level of real salary can also be taken into account as a welfare measure for the population due to its relationship with the general price index and therefore with the cost of living.

The main objective of the current study is to analyze the determinants of real wages in Mexico under the rational expectations hypotheses by means of the ge- 
neralized method of moments for the period 1998.1-2011.4. We assume that the labor market responds to the variations of the real wage and this one, to its determinants in compliance with the economic theory, but considering that unemployment is the main factor of fixation of salaries in Mexico and that productivity has a very important role in its fixation. Mexico is an open economy with a high degree of integration with its neighbor the United States of America, which influences its productive structure and therefore, indirectly, the determination of its wages. Other open economies with high degrees of integration into economies larger than them could be reflected in the findings of this research, such as Canada, which is also integrated into the United States.

The work consists of seven sections. In the first, the theoretical discussion of the determinants of real wages takes place, starting with the first classical conceptions of the labour market, Keynes' contributions on effective demand and institutional factors, and ending with the mainstream labor market, where the determinants of wages are inflation expectations, labor productivity and the unemployment rate. The second section reviews the background work devoted to studying the determinants of real wages in Mexico.

The third section shows the model specification for the case of Mexico; in the fourth, the main stylized facts of the variables involved in the estimation; in the fifth, the general method of moments methodology (GMM) is presented, in the sixth presents the model estimation and the discussion of results. Finally, in the seventh section an analysis of rigor is presented on the estimated model. The last part presents the conclusions of the study, which suggests that the determination of real wages in Mexico depends on labor productivity, on an important mechanism of wage restraint through unemployment and the stabilization of inflation, thus validating the Phillips curve in its accelerationist version and maintaining the determinants of wages as stated in the mainstream economic theory of the labor market.

\section{Theoretical Factors}

The economic theory distinguishes two kinds of wages; real wages and monetary wages. The distinction is important given that neoclassical school and further approaches consider real wages as the relevant variable in determining the employment volume inside the working market.

As for Keynesian theory, it rejects the existence of labor market and real wages as the key variable in the determination of employment given that for this current, employment is established by the effective demand and not by a wage negotiation process [2].

On the other hand, wage determination involves a great institutional influ-

${ }^{1}$ The estimation starts in that period because the Bank of Mexico, initiates with the outline of inflation targets through the "monetary act", although formally they weren't admitted by the monetary authority as an outline until 2001 [1]. 2011.4 is taken as the last data, because the National Institute of Statistics and Geography (INEGI) of Mexico, changes its methodology for the estimation of productivity and other indicators in 2012, which generates a structural change in variables. 
ence. For instance, the unionization which has as a main purpose the collective bargaining of workers with companies and which can be held inside the individual company to a sectorial or national level [3].

In Mexico, collective bargaining is very important. However, bilateral salary agreements between a company and its workers are the most common way of wage fixation considering that particularly the qualifications workers have for certain works are those which mostly determine the wage levels, reason for which the most qualified workers have more bargaining power (Chavez, 2010).

Not only salaries are determined institutionally (unions, unemployment insurance, unemployment insurance duration, career, perks, among others) but also with economic factors which are linked to the performance of all the economy. This means, a raise on the aggregate demand causes a competition between companies for hiring more work. That is how workers get more bargaining power and can raise their salaries. This process can be formulated the other way around when aggregate demand decreases [3].

On an international level, it's been increasingly recognized the need to apply sustainable wage policies which can increase the levels of remuneration of the millions of poor workers in the world and reinforce the consumption as a mainstay of a sustainable economy to achieve the eradication of wage inequality in the working place [4], and at the same time influence the effective demand, in a Keynesian way.

Current and lagging unemployment also play a significant role in wage determination, the reason is that wage pressures don't correspond with current unemployment but with long-term unemployment. Hence, it is argued that it exists a Non-Accelerating Inflation Rate of Unemployment (NAIRU) which implies the stability among wages and unemployment [5].

This way, if the unemployment rate is lower than NAIRU it is likely that wage pressures increase and consequently, inflation. While an unemployment rate higher that NAIRU will imply a decrease of wage pressures and alongside a fall in inflation. That is why it is important to consider not only current unemployment, but also lagging unemployment as a fundamental wage determinant.

On the other hand, labor productivity is a mainstay determinant for wage determination, especially in the long term. Labor is supposed to be constant in national GDP (that is, totally paid wages as a percentage of the total income), in such situation the rate of wage growth is equal to the growth rate of labor productivity.

Studies on determinants of real wages and nominal wages are variable and with different approaches. One of the most representative in terms of nominal wage is the one proposed by Blanchflower and Oswald [7] [8], who conceived an inverse relationship between the rate of local unemployment and individual wage, during the 90s. Such statistical relationship is known in economic theory as the wage curve.

Those authors in their seminal work called "The Wage Curve" [8], sustain the existence of a stable flexibility in the parameters along time and highly similar 
between the studied countries. Moreover, they mention that the common belief, in which workers who join industries or regions with a high level of unemployment enjoy a higher wage scale, is not correct ${ }^{2}$.

The former statement proceeds from the inverse relationship proposed between the wage scale and unemployment, since it implies that a worker from an industry or region with a high unemployment rate earns less than an identical worker from an industry or region with a low unemployment level.

This way, in Blanchflower and Oswald's studies [8], it is found that the magnitude of flexibility between the wage scale and unemployment is similar among countries. Given that the magnitude of the wage curve estimated for the United States economy is similar to the one recorded in the United Kingdom, Canada and Norway.

It is important to mention that there is an evident theoretical association between the Phillips curve and the wage curve since both state a negative relationship between wages and unemployment. Nevertheless, they differ as follows:

1) The Phillips curve was proposed as a mechanism of adjustment in situations of imbalance. The wage curve is a balance relationship which is not the description of a temporary phenomenon.

2) The Phillips curve relates changes in wages with the level of unemployment. The wage curve relates the wage level with that of unemployment.

3) The Phillips curve is traditionally calculated with macroeconomic data, the wage curve offers more value to microeconomic data.

For its part, the mainstream of the labor market, mentions that the determinants of real wages are: a) inflation expectations, b) labor productivity, and c) unemployment rate [3].

The relationship between real wage and inflation expectations entails making an assumption about its origin. On that subject, the most important development to explain them is the Rational Expectations Hypotheses (REH) by Lucas $[10]^{4}$, which postulates that by means of the available information, the economic agents don't commit systematic mistakes in their predictions.

The inflation expectations are essential to the study of labor market and the behavior of salaries due to the fact that those establish the level of salary-aspiration as requested by the workers, so that when there comes a raise in the inflationary expectations in the following period, the workers adjust their wage expectations to the rise, in this way it is obtained a real current value salary higher to the one

\footnotetext{
${ }^{2}$ Based on the works of Todaro and Harris [9], there was a well-defined agreement in which it was believed the existence or a positive relationship between salaries and unemployment, which was supported on regional studies. That is why it was believed that the regions with a high level of unemployment would be regions with high level of wages. If not, workers would emigrate from those regions, because they wouldn't tolerate persistent unemployment unless they would be compensated with high wages.

${ }^{3}$ The evidence presented by authors in their seminal work doesn't support. Hence, they maintain that the traditional theoretical framework of offer and demand is a mistaken framework to analyze labor market.

${ }^{4}$ Robert Lucas retakes the original idea of rational expectancies from Muth's seminal work [11]; "Rational Expectations and the Theory of Price movements".
} 
in the former period, opposite to this, a lower inflationary expectation results in a decrease of the salary-aspiration level.

To Friedman [12], and Phelps [13], the fluctuations in salary-aspiration lead to the balance of the labor market because they adjust the real wage with the real expected salary because they are negotiated in the following period upon a certain nominal-wage basis and a price expectation, and this way the aspiration-salaries are paired with the real current value salary, achieving the balance of the labor market.

This way real wage depends on the changes upon inflation expectations. On the other hand, the Phillips curve ${ }^{5}$ [6], is one of the most important references in the study of wage determinants, such work is based on a statistical analysis on the fluctuation suffered by the exchange rate of nominal wages regarding unemployment fluctuations finding a negative and "stable" relationship between the two variables. Even son, authors like Lepsey [16] and Friedman [12] have criticized and abounded theoretically the empirical relationship proposed originally by Phillips and in his version with adaptive expectancies, they associate that the changes in real wage ${ }^{6}$ are linked to the change in prices, therefore they assume that the salary influences importantly the inflation determination.

For that reason, the Phillips curve widened by adaptive expectations, associates negatively in the short term, the speed of the exchange rate of inflation to the effective unemployment rate and the existence of a Non-Accelerating Inflation Rate of Unemployment (NAIRU) in the long term. Therefore, unemployment influences importantly the determination of real wages because in the short term there is an exchange between inflation and unemployment, which implies that a rise in unemployment should reduce the salary-aspirations of workers and this way, can control demand-pull inflationary pressures, lowering prices due to an increase of unemployment, so that unemployment is a means of wage control and therefore, of inflation.

In economics literature the variable that has a major influence in determination of real wages is productivity and both variables keep a positive relationship [17]. From this theory we can imply that job productivity is the quotient between production $(\mathrm{Y})$ and the amount of work $(\mathrm{N}), \mathrm{Y} / \mathrm{N}$. And it grows as a consequence of technical progress and of accumulation of capital per worker, for that reason productivity is established internally within companies and so, salary should be equal to the productivity of the worker.

However, in the labor market there are institutional stiffness such as: unemployment insurance, minimum wage law and the existence of unions which perform collective negotiations which stop the real wage from adjusting to a balance

${ }^{5}$ The current version of the Phillips curve is the so called "new Keynessian Phillips curve" proposed by Galí \& Gertler [14], which emerges from its microfundamentation and shows the relationship between inflation and product gap, under the assumption of monopolistic competence and nominal stiffness [15].

${ }^{6}$ An important contribution from Friedman Lipsey to the Phillips curve theory is the recovery of the classical vision of real wages as the variable of adjustment in the labor market and not nominal wages as it is assumed by Phillips in his seminal article. 
level obtaining significant increases in the effective unemployment rate. This way the stiffness of labor market affects directly the constitution of real wage and contrasts with the theoretical conception of perfect competence in labor markets, therefore it is necessary to understand the way in which real salary is set in a frame of monopolistic competition. In the present investigation, the labor market is modeled through similarities of supply and demand curves in monopolistic competition, supply is obtained by a price setting function and demand by the wage determination function.

\section{State of the Art}

To Mexican economy, the studies about real and nominal wage behavior are relatively abundant, in spite of high complexity of the mechanism of the labor market, since the job market doesn't behave as a perfectly competitive and totally flexible market, due to the fact that in some economic sectors, wages are more rigid than in other sectors [18].

Besides, it is mentioned that Mexican labor market in a highly heterogeneous market in the qualification of the labor force, which is the reason that it cannot be conceived a single labor market, but it must be admitted the existence of many markets that claim for employment. However, although they are different, they are interconnected by competing for jobs.

For their part, Islas-Camargo and Cortez [19] mention that most of the works upon labor market in Mexico are centered in the study of wage inequity and try to explain their behavior. However, just like Rodriguez [18] they state that the labor market shouldn't be seen as a unique and integrated market since it is structured as many regional labor markets that are somehow interrelated.

On the other hand, Robertson [20] and Hanson [21], (citation taken from Islas-Camargo and Cortez [19]) mention that "Mexican labor market presents significant differences in the level of integration to the international economy, which has induced a differentiated wage behavior among regions. In other words, given those regional differences, it is expected that a certain external clash causes differentiated wage dynamics among regions"

From the geographic proximity (Statistical Appendix), most of Mexican economic integration is with the US. According to data from the National Institute of Statistics and Geography [22] in 2017 the US was the origin of $46 \%$ of Mexican imports, the destination of $80 \%$ of its exports and the origin of $47 \%$ of foreign direct investment received. All of that regardless of the investments that big American companies have had for years in various sectors in Mexico, especially in the financial, automobile and manufacturing sectors.

Moreover, Robertson [20] states that there is a close relationship between the labor market in the US and in Mexico and both are highly integrated. He considers that the changes in the labor market in the United States have direct effects upon the Mexican labor market. Hence, the initial wage difference between 
both economies is restored after the adjustment period. And that is why he claims that there is a major integration in the American labor market with those in the Mexican border compared to that of that of those labor markets inside the country.

That said, the present work is a pioneering effort to verify in a general way the determination of wages in an integrated economy like Mexico under the conception of the mainstream labor market, where wages are determined by inflation expectations, labor productivity and the unemployment rate.

\section{Model Specification}

Departing from the model exposed by Layard, Nickell and Jackman [3] which is fundamentally based in two equations. One of them is for price fixation and the other for wage fixation, being a comparison of the functions of labor offer and demand. The prices will depend on a Mark-up upon expected wages $\left(w^{\mathcal{L}}\right)$, meanwhile wages depend on a Mark-up upon expected prices $\left(p^{\mathrm{e}}\right)$, and so two functions are obtained:

$$
\begin{gathered}
p-w^{e}=\beta_{0}-\beta_{1} u \\
w-p^{e}=\gamma_{0}-\gamma_{1} u
\end{gathered}
$$

where $p$ (prices) and $w$ (nominal wages) are stated in logarithms, $u$ is the unemployment rate, $\beta_{0}$ and $\gamma_{0}$ are the parameters which represent the Mark-up and $\beta_{1}$ and $\gamma_{1}$ are the parameters which represent the flexibility of the model. The assumption that the parameters $\beta_{0}, \beta_{1}, \gamma_{0}$ and $\gamma_{1}>0$ is adopted.

The equations of wage fixation and prices suppose that to be in balance it is necessary that $w^{e}-w=p^{e}-p=0$. From Equations (1) and (2) it is obtained that the balanced unemployment rate is:

$$
u^{*}=\frac{\beta_{0}+\gamma_{0}}{\beta_{1}+\gamma_{1}}
$$

However, this unemployment rate can be modified because of changes in structural parameters associated to institutional factors such as changes in the minimum wage regimes, in perks of unemployment, unionization, etc.

These nominal surprises generate mistakes on the creation of expectations of the economic agents, therefore, $w^{e}=w=p^{e}=p$ is different to zero. As a consequence, the fluctuations in the unemployment rate observed, will depend on the existence of an acceleration or deceleration process in prices or correspondingly, in nominal wages. So, any factor that increases wages exogenously $\left(\gamma_{0}\right)$, or prices $\left(\beta_{0}\right)$, hoists the balance rate and if any exogenous factor raises the flexibility of real wages $\left(\gamma_{1}\right)$, or the flexibility of prices $\left(\beta_{1}\right)$ it reduces the balance rate. If the expected values of prices and salaries aren't met it is required:

$$
u=\frac{\beta_{0}+\gamma_{0}-\left(p-p^{e}\right)-\left(w-w^{e}\right)}{\beta_{1}+\gamma_{1}}
$$

or, 


$$
u=\frac{u^{*}-\left(p-p^{e}\right)-\left(w-w^{e}\right)}{\beta_{1}+\gamma_{1}}
$$

Supposing that wage and price surprises are similar, there is:

$$
u=u^{*}=\frac{-1}{\theta_{1}\left(p-p^{e}\right)}
$$

where $\theta_{1}=\frac{\beta_{1}+\gamma_{1}}{2}$, is an indicator of flexibility of real wages and of prices, therefore a low unemployment goes together with some positive surprises of prices. Le's suppose that we are into a period when inflation $(\Delta p)$, doesn't have any long-term tendency and inflation has a random route and hence variations in inflation are stable, so we have:

$$
\Delta p=p_{t-1}+\varepsilon
$$

where $\varepsilon$ is a random stable disturbance and under rational expectations we obtain:

$$
p^{e}=E(p)=p_{t-1}-\Delta p_{t-1}
$$

Consequently, the price surprise, $p-p^{\mathrm{e}}$ is:

$$
p-p^{e}=p-p_{t-1}-\Delta p_{t-1}=\Delta p-\Delta p_{t-1}=\text { Variation of inflation . }
$$

The price surprises are equal to the raises of the inflation. The same happens with salaries. Therefore, the Equation (5) is in general term a classic Phillips curve:

$$
\Delta p-\Delta p_{t-1}=-\theta_{1}\left(u-u^{*}\right)
$$

When unemployment is lower to $u^{*}$, inflation is rising. If unemployment is higher than $u^{*}$ inflation diminishes. Thus, it is reasonable to think that $\mathrm{u}^{*}$ is Non-Accelerating Inflation Rate of Unemployment (NAIRU) ${ }^{8}$. This way and according to Layard [3] inflation will only be kept stableif real wage wished by those responsible for setting wages is the same as the one wished by those who are responsible of setting prices. The variable that makes them compatible is the level of unemployment. Thus, inflation will only be kept stable if unemployment rate is within NAIRU.

\section{Stylized Facts}

Before starting with the estimation of the model, it is important to analyze the evolution of the series involved. The data which were used come from the Mexican Bureau of Statistics (INEGI) and their frequency is quarterly. The period in study starts the first quarter of 1998 and ends on the fourth quarter of 2011. The sample was chosen due to the fact that it is from 1998 when effective inflation starts to anchor to inflation expectancies by means of inflation objectives.

Productivity ( $Z$ ): it was made up by dividing the index of volume of manufacturing production base 1993 by the total of worked hours in the manufacturing ${ }^{8}$ NAIRU which stands for Non-Accelerating Inflation Rate of Unemployment. 
industry. To this index, a growth rate was applied, getting a stationary series.

Real wage (salreal): it is the mean man hour pay in the manufacturing sector in real terms, a growth rate was applied, getting a stationary series.

Rate of unemployment ( $u$ ): rate of open unemployment.

Inflation expectations (exin): these were built from lagged inflation $\inf _{\mathrm{t}}=\inf _{\mathrm{t}-1}$, and to this lagged inflation a lagging operator was applied by means of the following inflation relation: $\Delta \mathrm{inf}=\left(\mathrm{inf}_{\mathrm{t}}-\mathrm{inf}_{\mathrm{t}-1}\right)^{9}$, this way, inflation variations can be translated as a proxy variable of inflation expectations.

US Industrial Product (proin): it is the growth rate of US Industrial Product.

Mexican quarterly GDP (PIB): this is the quarterly GDP growth of Mexico ${ }^{10}$.

In Table A1, (see Statistical Appendix), we can appreciate that the maximum real wage variation is 7.18 pesos, and that its mean is only 0.40 pesos, which means in general terms that real wage has been kept stagnant within the period of the sample. However; the same phenomenon can be appreciated with the variation of productivity which has also been kept stagnant due to the fact that its changes are too small. On the other hand, the unemployment rate seems to have very little variation, as well; since its standard deviation is only $1.1 \%$, in spite of the great 2009 crisis. Nonetheless, it must be taken into account that methodology to calculate unemployment in Mexico does not consider the informal sector and under-employment which are significant in the country. Another important phenomenon of the series is that even though the GDP variation which is 3.3\% of real wages, it has not presented significant raise which may indicate that wages do not respond directly to GDP fluctuations.

In Figure 1, Inflation expectation series are shown, US Industrial product, real wage, unemployment rate, GDP and productivity. Variables such as unemployment, GDP and American Industrial Product are stated in percent, whereas Inflation expectations and productivity are indexes and real wage is expressed in pesos.

It is important to state that expectation series of inflation, industrial product, productivity and GDP are stationary series whereas real wage rates and unemployment rates are non-stationary, therefore they follow random process ${ }^{11}$. On the other hand, it can be appreciated that during 2009 recession the GDP growth rate in Mexico and the Industrial US product had an important slump being 9.7\% and $22.3 \%$ respectively, which explains that the unemployment rate in Mexican economy raised in such a significant fashion during this period being its highest spike $7.8 \%$ for its partinflation expectation (exin), for the same period of time was diminishing due to the fact that the economic agents being involved in a downturn set a deflationary expectation-coherent to Figure 2. Nonetheless, and in spite of deflation, real wage variation was not so drastic, and productivity decreased but no in a significant fashion.

${ }^{9}$ The lagging operator was established by subtracting the original time series and a specific lagged series therefore, the relationship between $\Delta y B$ is: $\Delta=1-B$ that is to say $\Delta \pi=(1-B) \pi=\pi_{t}-\pi_{t-1}$.

${ }^{10}$ In Table 1, descriptive statistics are presented of each of the variables. See Statistical Appendix.

${ }^{11}$ See tests for unit roots in Statistical Appendix. 
SALRE
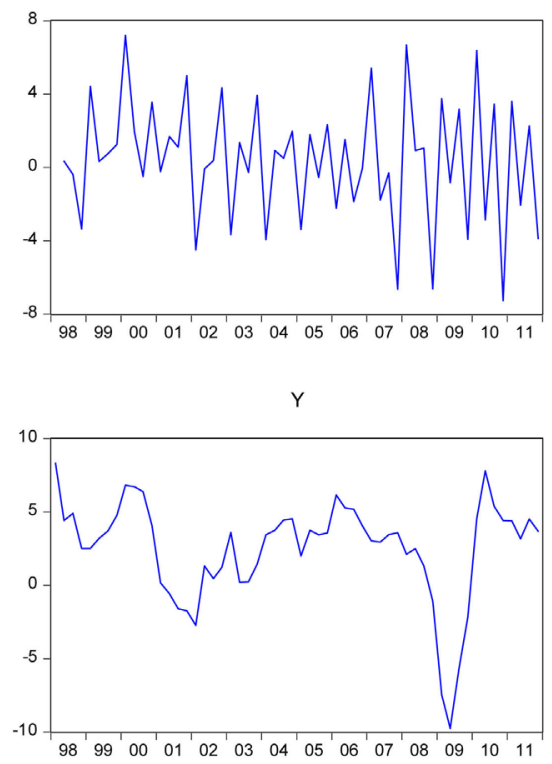

EXIN

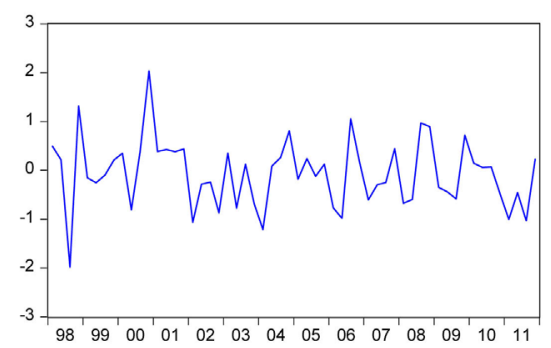

$\mathrm{U}$
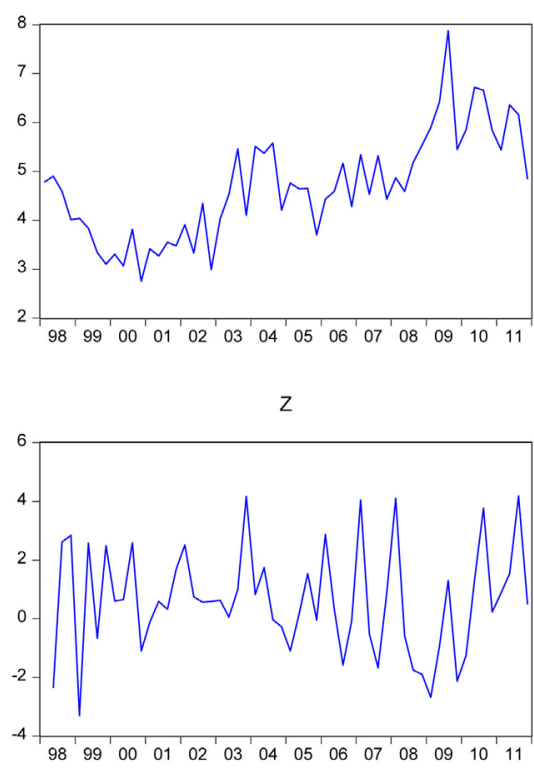

PROIN

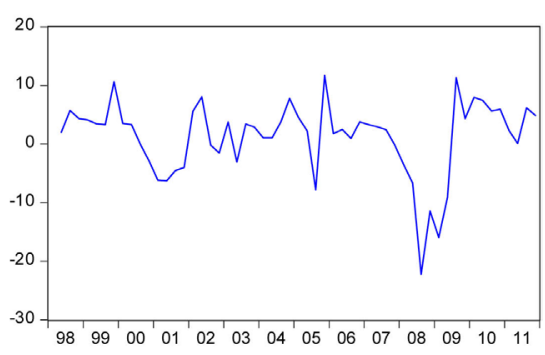

Figure 1. Series involved in estimation. Source: Estimated based on INEGI.

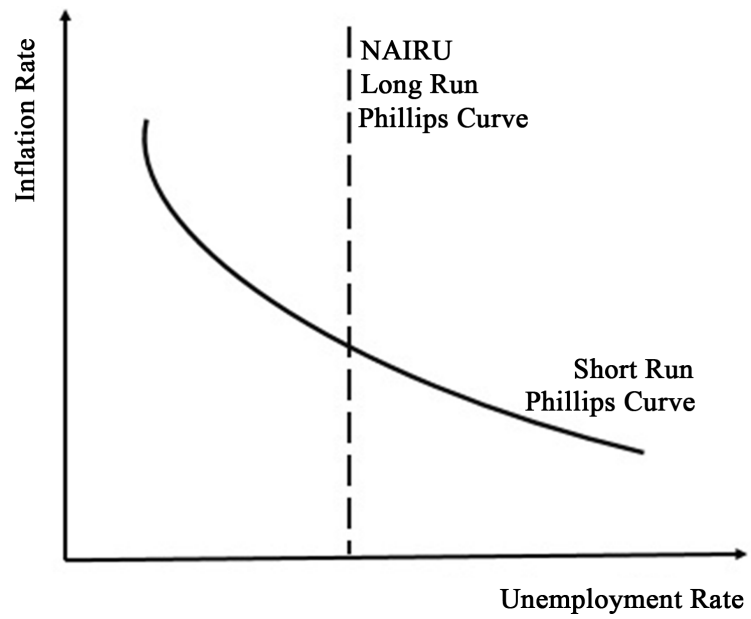

Figure 2. Phillips curve [6]. Source: Own elaboration.

\section{Methodology}

Once used variables in the estimation were defined and the main facts of the series were stylized, we proceeded to estimate our model through a General Moment Method (GMM) which offers the possibility to adjust a rational expecta- 
tion model into an econometric one. While there are other important techniques for modeling for such expectations such as two-stage least squares, and instrumental variables, they are inefficient with parameters due to problems of autocorrelation and heteroscedasticity. Whereas GMM is able to avoid this problem for it is not necessary to fully specify the probability model, this way we can prevent parameter loss of efficiency [23], furthermore. With GMM it is not required establish a special distribution to the error term, which is the most suitable in case of rational expectations where economic agents use all available information to carry out their forecasts [24].

Since the General Moment Method (GMM) is determined by the conditions of orthogonality, it only needs that unknown parameters are equaled as repeatedly as necessary, this way there is a correspondence between the sample moments and the unknown parameters, obtaining a moment estimator for an unobservable parameter [23].

The orthodox theory of labor market determines

$$
\frac{w}{p}=f\left(\Delta p_{t+1}^{e}, Z, U\right)
$$

where:

$$
\begin{aligned}
& \frac{w}{p}=\text { Real wage } \\
& \Delta p_{t+1}^{e}=\text { Expected inflation rate } \\
& Z=\text { Productivity } \\
& U=\text { Unemployment rate }
\end{aligned}
$$

Equation (7) states that an increase in labor productivity has a positive effect over real wages, due to the fact that an increase in productivity represents an increase in production per person employed. On the other hand, real wage maintains a negative relationship with unemployment since an increase in real wages will raise demand of consumption goods and will cause inflationary pressures, which will be reduced with an increase of unemployment (proxy in Phillips curve). For their part, real wage movements correlate to changes in inflation expectations. For that matter, real wage diminishes when there is a prevision of raise in inflation expectations or with an increase if forward inflation expectations diminish. Thus, assuming that economic agents build their expectations in a rational fashion, inflation expectation may be defined as the expected inflation rate in $t+1$, conditioned to a set of available information $\left\{\Omega_{t-j}\right\}$ for the agents in a period $t-j[25]$.

$$
\Delta p_{t+1}^{e}=E\left[\frac{\Delta p_{t+1}}{\Omega_{t-j}}\right], j \geq 0
$$

An assumption of rational expectations implies that the set of information must be orthogonal in regard to errors, for agents do not make mistakes systematically in their forecasts, thus the condition of orthogonality is fulfilled when the information vector conditioned to errors of estimation equals zero. 


$$
E\left[\frac{\Omega_{t-j}}{u_{t}}\right]=0
$$

It is necessary to claim that the GMM requires defining instrumental variables for the implied variables in the estimating equation in order to satisfy the orthogonality condition ${ }^{12}$ to ensure efficient estimators. Therefore, Equation (8) is used to prove that real wage setting by means of a group of instrumental variables $\left(Z_{t-j}\right)$, in a frame of rationale expectations by the economic agents.

\section{Estimation and Results Discussion}

The value of estimated parameters upon the determinants of real wages by GMM show that the unemployment rate is the most important factor in its determination. That is because rises in the unemployment rate have a negative effect on real wages, which is understood as a proxy of the Phillips curve, showing that the rise of $1 \%$ in the unemployment rate causes a fall in the real wage rate in a $70 \%$, so, in that sense it is the strategic variable for a restraint of inflation since it doesn't allow that salary-aspirations grow considerably avoiding inflationary pressures by means of demand. On the other hand, we found that inflation expectations during the studied period are positive and affect in the fixation of prices in a 52\%, which is consistent with the policy of inflation goals, given that a rise in inflationary expectancies brings about rises in salary-aspirations affecting positively the exchange rate of real wages. On its part, productivity, which is the variable most associated theoretically in wage determination [17], has a relevant effect in real wages in our estimation, because a rise in the exchange rate of productivity affects positively and in a $67 \%$ on the variation rate of real wages, which shows that the process of determination of salaries depends widely on marginal productivity of labor as such and as economic theory stablishes.

$$
\begin{gathered}
w / p=3.53+0.524 \Delta p_{t+1}^{e}+0.676 Z_{t}-0.708 U_{t}+5.23 d u m+e_{t} \\
t \quad(7.01)(2.02) \quad(10.22) \quad(-7.40) \quad(32.45)
\end{gathered}
$$

$\mathrm{R}^{2}=0.78 ; \mathrm{DW}=2.69 ;$ Number of instruments $(31)^{13} ; \mathrm{J}$-Statistic $=11.34$ $(0.994)^{14}$; Endogeneity test $=0.1780(0.9810)$, Jarque-Bera; $1.892(0.388)$. The remains of the estimation are stable. $\mathrm{I}(0)$, therefore, the cointegration is validated (see Statistical Appendix).

The instrumental variables used in the system are: the GDP growth rate in

${ }^{12}$ Orthogonality conditions are determined by moment conditions and not by the function of probability density. Thus, it depends on the expectancy of the cross product divided by the random shock and the observable variables in a model equalizing zero. These random shocks, which are not observable, may be replaced by an expression equivalent that is expressed in the function of the true parameter vector and the observed variables [24].

${ }^{13} \mathrm{c}$ y y $(-1)$ y $(-2)$ y $(-3)$ y $(-4)$ y $(-5)$ proin proin $(-1)$ proin $(-2)$ proin $(-3)$ proin $(-4)$ proin $(-5)$ proin $(-6)$ proin $(-7)$ exin exin $(-1)$ exin $(-3)$ exin $(-4) \mathrm{u}(-1) \mathrm{u}(-2) \mathrm{u}(-3) \mathrm{u}(-4) \mathrm{u}(-5) \mathrm{z}(-1) \mathrm{z}$ $(-2)$ salre $(-1)$ salre $(-2)$ salre $(-3)$ salre $(-4)$ salre $(-5)$.

${ }^{14}$ Hansen's J statistics shows that if one or more of the instruments are not valid. For the present estimation it can be observed that the J Statistics indicates that all the instruments of the estimation are valid to a $95 \%$ of a trust level. 
Mexico (Y), the industrial product in the US and the lagged series of the variables estimated up to 7 lags, make the vector of information that the economic agents use to obtain their rational expectancies, which are valid through Hansen's J statistics.

\section{Robustness Testing}

\subsection{Wald Test}

In order to check the relationship between the dependent and independent variables, the Wald test was applied to the parameters. In which no proportional marginal changes in the estimators are assumed as a hypothesis. In all cases, the null hypothesis is rejected; with respect to real wages, the result of the test indicates that there are no proportional marginal changes between the explanatory variables and the independent variable (See Table 1).

\subsection{Instrument Orthogonality Test}

Under the two-stage procedure of instrumental variables it is necessary that the number of instruments be greater than the number of parameters. Therefore, a test was applied to determine the non-over-identification of the model, which consists of assuming as a null hypothesis that the over-identified restrictions comply with the orthogonality condition. The results show that the estimated model does not present any specification problems (See Table 2).

\subsection{Regressor Endogeneity Test}

The endogenous regressor test is also known as the Durbin-Wu-Hausman test, and tests the endogeneity of some, or all, of the equation's regressors. A regressor is endogenous if explained by the instruments involved in the model, while exogenous variables are those that are not explained by the instruments. In the estimate using the General Method of Moments (GMM), exogenous variables can be specified by including a variable such as a regressor and an instrument, while endogenous variables are those specified in the list of regressors only. Therefore, the endogeneity test checks whether a subset of endogenous variables is actually exogenous (See Table 3).

\subsection{Hypothesis Test of Rational Expectations}

On the other hand, the testing of the Rational Expectations hypothesis requires that the prediction error be independent of the set of information used and the test can be specified as follows [11]: (See Table 4)

Table 1. Wald test on parameter restriction.

\begin{tabular}{ccc}
\hline Test & Value & Probability \\
\hline F-statistic & 143.544 & 0.000 \\
$\chi^{2}$ & 430.634 & 0.000
\end{tabular}


Table 2. Test-C on the orthogonality of the instruments.

\begin{tabular}{ccc}
\hline Test & Value & Probability \\
\hline Test-C & 0.1285 & 0.9377 \\
\hline
\end{tabular}

Table 3. Test Endogeneity Regressor.

\begin{tabular}{ccc}
\hline Test & Value & Probability \\
\hline Difference in J-Stats & 0.0537 & 0.9735 \\
\hline
\end{tabular}

Table 4. Orthogonality Test of the information set $\left[\left(\Delta \operatorname{exin}_{t+1}\right)=\frac{\alpha}{\Omega_{t-j}}+v_{t}\right]$.

\begin{tabular}{ccccc}
\hline Variable & Coefficient & Std. Error & t-Statistic & Prob. \\
\hline $\mathrm{C}$ & -0.041167 & 0.122527 & -0.335980 & 0.7397 \\
$\mathrm{D}(\mathrm{Z}(-1))$ & -0.066238 & 0.085198 & -0.777459 & 0.4442 \\
$\mathrm{D}(\mathrm{Z}(-2))$ & -0.020679 & 0.098164 & -0.210657 & 0.8349 \\
$\mathrm{D}(\mathrm{Z}(-3))$ & 0.034932 & 0.124903 & 0.279669 & 0.7820 \\
$\mathrm{D}(\mathrm{Z}(-4))$ & 0.036701 & 0.128646 & 0.285283 & 0.7778 \\
$\mathrm{D}(\mathrm{Z}(-5))$ & -0.057047 & 0.124265 & -0.459075 & 0.6501 \\
$\mathrm{D}(\mathrm{Z}(-6))$ & -0.061444 & 0.110857 & -0.554259 & 0.5843 \\
$\mathrm{D}(\mathrm{Z}(-7))$ & -0.059130 & 0.072212 & -0.818844 & 0.4206 \\
$\mathrm{D}(\mathrm{U}(-1))$ & 0.030671 & 0.257457 & 0.119132 & 0.9061 \\
$\mathrm{D}(\mathrm{U}(-2))$ & 0.226493 & 0.264896 & 0.855025 & 0.4007 \\
$\mathrm{D}(\mathrm{U}(-3))$ & -0.116149 & 0.254594 & -0.456212 & 0.6522 \\
$\mathrm{D}(\mathrm{U}(-4))$ & -0.100977 & 0.232952 & -0.433469 & 0.6684 \\
$\mathrm{D}(\mathrm{U}(-5))$ & 0.180174 & 0.238910 & 0.754153 & 0.4578 \\
$\mathrm{D}(\mathrm{U}(-6))$ & -0.017801 & 0.242798 & -0.073316 & 0.9421 \\
$\mathrm{D}(\mathrm{U}(-7))$ & 0.217992 & 0.215688 & 1.010681 & 0.3219 \\
$\mathrm{D}(\mathrm{EXIN}(-1))$ & -0.738909 & 0.244516 & -3.021926 & 0.0057 \\
$\mathrm{D}(\mathrm{EXIN}(-2))$ & -0.626565 & 0.268277 & -2.335517 & 0.0278 \\
$\mathrm{D}(\mathrm{EXIN}(-3))$ & -0.400022 & 0.304176 & -1.315100 & 0.2004 \\
$\mathrm{D}(\mathrm{EXIN}(-4))$ & -0.477671 & 0.308493 & -1.548401 & 0.1341 \\
$\mathrm{D}(\mathrm{EXIN}(-5))$ & -0.389481 & 0.323820 & -1.202773 & 0.2403 \\
$\mathrm{D}(\mathrm{EXIN}(-6))$ & -0.601235 & 0.288369 & -2.084954 & 0.0474 \\
$\mathrm{D}(\mathrm{EXIN}(-7))$ & -0.220992 & 0.246787 & -0.895476 & 0.3791 \\
\hline & & & & \\
\hline & & & & \\
\hline & & & & \\
\hline
\end{tabular}

$$
\left(\Delta \operatorname{exin}_{t+1}\right)=\frac{\alpha}{\Omega_{t-j}}+v_{t}
$$

Under the context of the previous equation $\left[\left(\Delta\right.\right.$ exin $\left.\left._{t+1}\right)=\frac{\alpha}{\Omega_{t-j}}+v_{t}\right]$, Accepting 
the Rational Expectations Hypothesis implies proving that $\alpha=0$. Therefore, a Wald test was applied, assuming that the null hypothesis that the parameters of the variables that define the information set are equal to zero. The F-statistics results $=1.743(0.0921)$, show that the forecast error is independent of the data set. This implies that the Rational Expectations Hypothesis is validated.

\section{Conclusions}

The results obtains by the GMM show that the determination of real wages depends on labor productivity, such as it is recorded in economic theory, and moreover, on an important mechanism of wage restraint by means of unemployment, which validates the existence of the Phillips curve in an acceleration version, therefore, it can be determined that the movements of real wages depends to a great extent on the stabilization of inflation (given that rises on real wages, must transform in inflation due to demand), reason why inflation and its inflation expectations must cling to the changes on the unemployment rate existing in economy.

This way the fixation of wages obeys to factors related with the labor market. On the other hand, the instruments used in the estimation are an important factor in salary determination, since the economic growth of Mexico and its bond with the economic cycle of the US operate positively on salary-aspirations due to the fact that it generates a rise of employment and the imminent fall in unemployment, implying getting out from the of the inflation target established by the monetary authorities which forces those responsible of policies to take restrictive measures to stop the pressures in prices, and that is obtained by raising unemployment constantly. It is because of them that it is viable that real wages in Mexico depend on the level of unemployment during the study period.

This result shows that the increases in productivity caused by the United States-Mexico relationship put pressure on inflation, given their positive effects on employment generation and better wage expectations, consequently, in order to curb inflation, it is necessary to maintain the highest unemployment rate than if inflation were higher than the objective set by those responsible for economic policy were accepted. In the period of study, the Mexican economy chose to maintain inflation close to its goal, sacrificing employment; however, the present study was done in an aggregate manner in the Mexican economy, it is possible that when considering the diversity of sectors and their integration into the United States, it is possible that in the sector with the greatest integration, the manufacturing industry, this increase in productivity will be taken advantage of by means of higher wages and in other sectors of the economy where unemployment adjustment occurs. This opens up the possibility for new research on this subject, especially the replication of the same on a sectoral basis, where it would be relevant to study the determination of wages in the export manufacturing industry in Mexico.

This research also sets a precedent for the determination of wages, and their implications for inflation and unemployment, in open economies with a high 
degree of integration into larger than study economies; for example, Canada, or the Asian countries linked to the large European economies, Japan and China.

\section{Acknowledgements}

The authors thank the anonymous referees for their comments to substantially improve this work. However, the authors are the only ones responsible for what is said or omitted in the present investigation.

\section{Conflicts of Interest}

The authors declare no conflicts of interest regarding the publication of this paper.

\section{References}

[1] Díaz de León, A. and Greenham, L. (2000) Política monetaria y tasas de interés: Experiencia reciente para el caso de México. Documento de investigación No. 2000-08. Banco de México.

[2] Keynes, J. (1936) The General Theory of Employment, Interest and Money. Fourth Edition, Fondo de Cultura Económica, México.

[3] Layard, R., Nickell, S. and Jackman, R. (1994) Los Resultados Macroeconómicos y el Mercado de trabajo. Ministerio de Trabajo y Seguridad Social, España.

[4] Organización Internacional del Trabajo (2016) Informe mundial sobre salarios 2016/017. La desigualdad salarial en el lugar de trabajo. OIT.

http://www.ilo.org/wcmsp5/groups/public/---dgreports/---dcomm/---publ/docume nts/publication/wcms_541632.pdf

[5] Blanchard, O., Alessia, A. and Giavazzi, F. (2010) Macroeconomics. Fifth Edition, Pearson Educación, Madrid.

[6] Phillips, A.W. (1958) The Relation Between Unemployment and the Rate of Change of Money Wage Rates in the United Kingdom, 1961-1957. Económica, 25, 283-299. https://doi.org/10.2307/2550759

[7] Blanchflower, D.G. and Oswald, A.J. (1995) The Wage Curve. MIT Press Books, The MIT Press, Cambridge, Volume 1, Number 026202375x.

[8] Blanchflower, D.G. and Oswald, A.J. (1994) Estimating a Wage Curve for Britain 1973-1990. Economic Journal, 104, 1025-1043. https://doi.org/10.3386/w4770

[9] Harris, J.R. and Todaro, M. (1970) Migration, Unemployment and Development: A Two Sector Analysis. The American Economic Review, 60, 126-142.

[10] Lucas, R. (1972) Expectations and the Neutrality of Money. Journal of Economic Theory, 4, 103-124. https://doi.org/10.1016/0022-0531(72)90142-1

[11] Muth, J.F. (1961) Rational Expectations and the Theory of Price Movements. Econometrica, 29, 315-335. https://doi.org/10.2307/1909635

[12] Friedman, M. (1968) The Role of Monetary Policy. American Economic Review, 58, $1-17$.

[13] Phelps, E. (1968) Money-Wage Dynamics and Labor Market Equilibrium. Journal of Political Economy, 76, 678-678. https://doi.org/10.1086/259438

[14] Galí, J. and Gertler, M. (1999) Inflation Dynamics: A Structural Econometric Analysis. Journal of Monetary Economics, 44, 195-222.

https://doi.org/10.1016/S0304-3932(99)00023-9 
[15] Bejarano, J. (2005) Estimación estructural y análisis de la curva de Phillips Neokeynesiana para Colombia. Ensayos sobre política económica, Banco de la Republica de Colombia.

[16] Lipsey, R. (1960) The Relation between Unemployment and the Rate of Change of Money Wage Rates in the United Kingdom, 1862-1957: A Further Analysis. Economica, 27, 1-31. https://doi.org/10.2307/2551424

[17] Hernández-Laos, E. (2002) El nexo productividad-salarios reales en las manufacturas mexicanas. Denarius, Revista de Economía y Administración, Vol. 4.

[18] Rodríguez, A. (2005) Dinámica del empleo y las remuneraciones reales en México: Evolución de los últimos treinta años y perspectivas. Departamento de Economía, Universidad Iberoamericana, México. D.F.

[19] Islas-Camargo, A. and Cortez, W. (2004) Regional Labor Market Integration: Northern Mexico and Southern USA. Universidad de Guadalajara, Guadalajara, Working Paper.

[20] Robertson (2000) Wage Shocks and North American Labor Market Integration. The American Economic Review, 90, 742-764. https://doi.org/10.1257/aer.90.4.742

[21] Hanson (2003) What Has Happened to Wages in Mexico since NAFTA? Implications for Hemispheric Free Trade. National Bureau of Economic Research (NBER), Cambridge, Working Paper 9563. https://doi.org/10.3386/w9563

[22] Instituto Nacional de Estadística, Geografía e Informática (2018) Banco de Información económica. http://www.inegi.org.mx

[23] Catalán, H. (2001) Paridad descubierta de tasas de interés mediante el método general de momentos. Momento económico. Núm. 113, enero-febrero.

[24] Denia, A. and Mauleón, I. (1995) El método generalizado de momentos. Instituto Valenciano de Investigación Económica, S.A. España.

[25] McCallum, B. (1989) Monetary Economic: Theory and Policy. McMillan, Nueva York. 


\section{Statistical Appendix}

Table A1. Descriptive statistics.

\begin{tabular}{ccccccc}
\hline & Sal. Real & $\mathrm{U}$ & $\mathrm{PIB}$ & $\mathrm{Z}$ & Exin & Proin \\
\hline mean & 0.40085 & 4.679818 & 2.410909 & 0.605951 & -0.078762 & 1.171626 \\
median & 0.51365 & 4.59 & 3.44 & 0.586279 & -0.096206 & 2.888282 \\
maximum & 7.189951 & 7.88 & 7.81 & 4.179404 & 2.032381 & 11.69279 \\
minimum & -7.262732 & 2.76 & -9.75 & -3.310874 & -1.977547 & -22.25883 \\
Standard deviation & 3.338404 & 1.099344 & 3.387548 & 1.814555 & 0.700059 & 6.370235 \\
bias & -0.217099 & 0.455361 & -1.505789 & 0.158971 & 0.199353 & -1.338914 \\
Skewness & 2.751697 & 2.929888 & 5.727098 & 2.591676 & 3.797032 & 5.551542 \\
Jarque-Bera & 0.573336 & 1.912011 & 37.82778 & 0.613744 & 1.820105 & 31.35258 \\
probability & 0.750761 & 0.384425 & 0 & 0.735745 & 0.402503 & 0 \\
sum & 22.04676 & 257.39 & 132.6 & 33.32729 & -4.331937 & 64.43942 \\
Sum of squares & 601.8267 & 65.2621 & 619.6759 & 177.8009 & 26.46443 & 2191.314 \\
Observations & 55 & 55 & 55 & 55 & 55 & 55 \\
\hline
\end{tabular}

Source: Estimated based on INEGI.

Table A2. Test for Unit Roots.

\begin{tabular}{|c|c|c|c|c|c|c|c|}
\hline \multicolumn{8}{|c|}{ Test for Unit Roots } \\
\hline & & sal. real & $\mathrm{u}$ & pib & $\mathrm{z}$ & exin & proin \\
\hline \multirow{3}{*}{$\mathrm{ADF}$} & Intercept & -2.278 & -1.508 & -3.423 & -7.404 & -7.484 & -3.984 \\
\hline & Intercept y tendency & -9.223 & -3.342 & -3.421 & -7.382 & -7.506 & -3.947 \\
\hline & nil & -2.463 & 0.110 & -2.65 & -6.615 & -7.457 & -3.93 \\
\hline \multirow{3}{*}{$(\mathrm{ADF})$} & Intercept & -6.205 & -3.202 & -5.563 & -8.046 & -7.377 & -10.25 \\
\hline & Intercept y tendency & -6.104 & -3.707 & -5.577 & -7.940 & -7.263 & -10.13 \\
\hline & nil & -6.232 & -3.201 & -5.711 & -8.111 & -7.466 & -10.305 \\
\hline \multirow{3}{*}{$\mathrm{PP}$} & Intercept & -12.273 & -2.502 & -3.045 & -7.419 & -7.484 & -4.087 \\
\hline & Intercept y tendency & -32.257 & -4.633 & -2.947 & -7.409 & -7.517 & -4.057 \\
\hline & nil & -11.747 & -0.343 & -2.600 & -6.350 & -7.457 & -4.020 \\
\hline \multirow{3}{*}{$(\mathrm{PP})$} & Intercept & -52.71 & -13.561 & -5.674 & -27.592 & -38.528 & -10.236 \\
\hline & Intercept y tendency & -52.288 & -13.478 & -5.600 & -28.152 & -39.642 & -10.164 \\
\hline & nil & -52.923 & -13.644 & -5.730 & -28.038 & -38.594 & -10.388 \\
\hline \multirow{3}{*}{ KPSS } & Intercept & 0.341 & 0.741 & 0.105 & 0.095 & 0.146 & 0.077 \\
\hline & Intercept y tendency & 0.107 & 0.094 & 0.060 & 0.075 & 0.049 & 0.059 \\
\hline & Intercept & 0.152 & 0.197 & 0.094 & 0.257 & 0.500 & 0.034 \\
\hline (KPSS) & Intercept y tendency & 0.118 & 0.196 & 0.039 & 0.193 & 0.500 & 0.030 \\
\hline
\end{tabular}

Unit-root test shows that the series of real wage, GDP, inflation expectation, productivity and the industrial product of the US are of integration order I(0). Meanwhile the rate of unemployment shows an integration order I (1). 
Table A3. Test for Unit Roots in residuals.

\begin{tabular}{lcc}
\hline & Test for Unit Roots in residuals & \\
\hline & & Residuals \\
\hline ADF & Intercept & -9.664 \\
& Intercept y tendency & -9.526 \\
& nil & -9.768 \\
(ADF) & Intercept & -8.745 \\
& Intercept y tendency & -8.647 \\
& nil & -8.847 \\
PP & Intercept & -10.048 \\
& Intercept y tendency & -9.963 \\
& nil & -10.162 \\
(PP) & Intercept & -35.875 \\
& Intercept y tendency & -36.277 \\
& Intercept & -36.332 \\
& Intercept & 0.145 \\
& Intercept y tendency & 0.137 \\
& Ins $)$ & 0.369 \\
& Intency & 0.346 \\
\hline
\end{tabular}

The unit-root test of the remaining estimated are of order of integration $\mathrm{I}(0)$. That is why it is allowed to infer that our estimation is cointegrated.

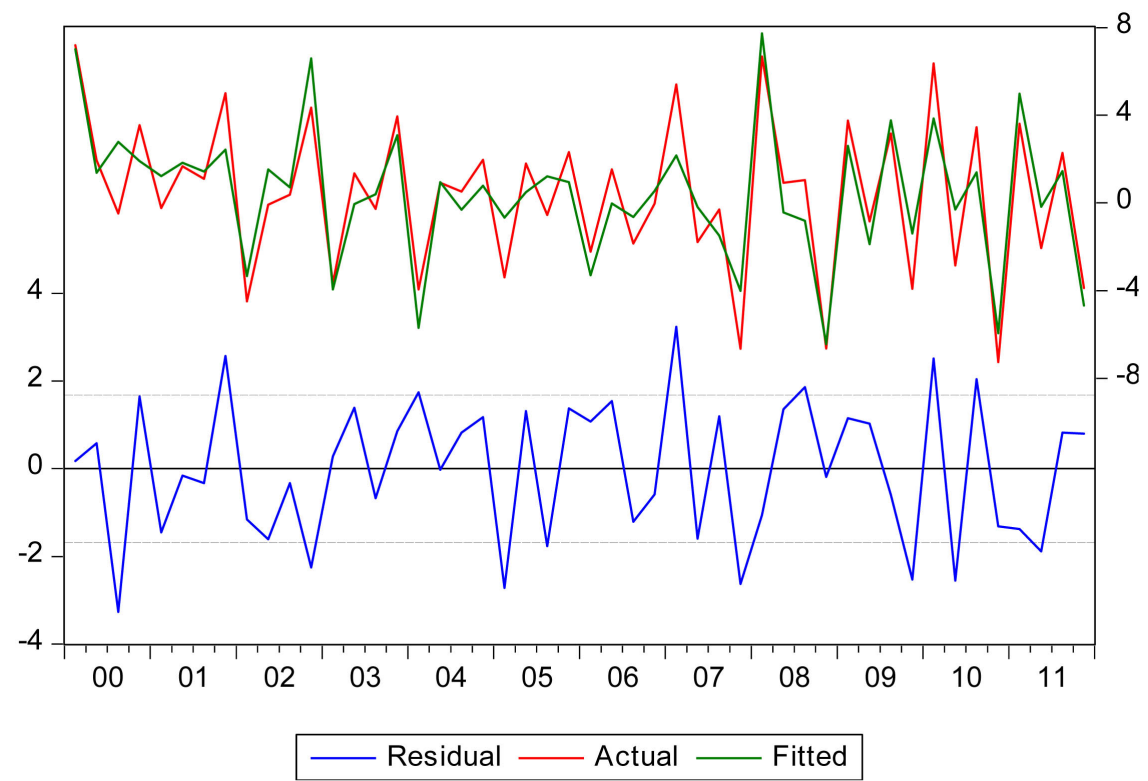

Figure A1. Estimated and residual values by the General Momentum Method. 